\title{
Use of Resistant Cultivars and Reduced Fungicide Programs to Manage Peanut Diseases in Irrigated and Nonirrigated Fields
}

\author{
J. E. Woodward, Former Graduate Student, T. B. Brenneman, Professor, and R. C. Kemerait, Jr., Associate Pro- \\ fessor, Department of Plant Pathology; N. B. Smith, Assistant Professor, Department of Agricultural and Applied \\ Economics; A. K. Culbreath, Professor, and K. L. Stevenson, Associate Professor, Department of Plant Pathology, \\ The University of Georgia, Coastal Plain Experiment Station, Tifton 31793
}

\begin{abstract}
Woodward, J. E., Brenneman, T. B., Kemerait, R. C., Jr., Smith, N. B., Culbreath, A. K., and Stevenson, K. L. 2008. Use of resistant cultivars and reduced fungicide programs to manage peanut diseases in irrigated and nonirrigated fields. Plant Dis. 92:896-902.

Field experiments were conducted in 2004 and 2005 to evaluate the response of several peanut cultivars to standard and reduced-input fungicide programs under production systems which differed in the duration of crop rotation, disease history within a field, or in the presence or absence of irrigation. Effects on early leaf spot (caused by Cercospora arachidicola), late leaf spot (caused by Cercosporidium personatum), and southern stem rot (caused by Sclerotium rolfsii), pod yields, and economic returns were assessed. Standard fungicide programs were similar for both sets of experiments and included applications of pyraclostrobin, tebuconazole, azoxystrobin, or chlorothalonil. Reduced-fungicide programs, comprising combinations of the aforementioned fungicides, resulted in two and four applications for the cultivar and irrigation experiment, respectively. Two additional programs (a seven-spray chlorothalonil and a nontreated control) were included in the cultivar experiment. Fungicide programs provided adequate levels of leaf spot suppression, and stem rot incidence was similar among fungicide programs within the two management systems. In the cultivar experiment, returns were significantly lower for the reduced program compared with the full program and seven-spray chlorothalonil program; however, they were significantly higher than the nontreated control. Significant differences in leaf spot, stem rot, and yield were observed among cultivars in both experiments. Overall, leaf spot intensity was lowest for the cvs. Georgia-03L and Georgia-01R and greatest for Georgia Green and Georgia-02C. Georgia-03L, Georgia-02C, and AP-3 consistently had lower incidence of stem rot than the other cultivars. Pod yields for all cultivars were equivalent to or greater than Georgia Green in both experiments; however, the performance of reduced-fungicide programs was inconsistent.
\end{abstract}

Additional keywords: Arachis hypogaea L., disease risk index

Fungal diseases are responsible for economic losses throughout peanut (Arachis hypogaea L.) production areas of the southeastern United States. Important foliar diseases are early leaf spot, caused by Cercospora arachidicola Hori, (teleomorph = Mycosphaerella arachidis Deighton), and late leaf spot, caused by Cercosporidium personatum (Berk. \& M.A. Curtis) Deighton, (teleomorph $=M y$ cosphaerella berkeleyi W.A. Jenkins). Stem rot, caused by Sclerotium rolfsii Sacc. (teleomorph = Athellia rolfsii C.C. $\mathrm{Tu} \&$ Kimbr.), and Rhizoctonia limb rot, caused by Rhizoctonia solani J.G. Kühn (teleomorph = Thanatephorus cucumeris (A.B. Frank) Donk), are important soilborne diseases. These diseases occur annu-

Corresponding author: J. E. Woodward

E-mail: jewoodward@ag.tamu.edu

Accepted for publication 1 November 2007.

doi:10.1094/PDIS-92-6-0896

(C) 2008 The American Phytopathological Society beginning 58 DAP, with chlorothalonil applications completing a seven-spray regime (29). The labeled use pattern for azoxystrobin consists of two applications, which generally are applied 60 and 90 DAP. Reports have indicated that azoxystrobin provides a level of stem rot control similar to that obtained with tebuconazole $(23,25)$, and it is also active on leaf spot; however, five additional applications of chlorothalonil typically are required for full-season leaf spot control (29). Despite the efficacy of tebuconazole and azoxystrobin, recommended programs involving either product require at least seven applications. Due to escalating production costs and suppressed crop value, reductions in input costs are needed if producers are to remain economically competitive.

Pyraclostrobin is a QoI fungicide that recently was registered for use on peanut. Previous reports indicate that pyraclostrobin provides levels of leaf spot control superior to chlorothalonil applied on similar schedules (10), and that pyraclostrobin applied at 21-day intervals was as effective as chlorothalonil applied at 14-day intervals (13). Because of the superior activity of pyraclostrobin, efforts have been made to integrate this product into programs with reduced numbers of fungicide applications. Culbreath et al. (13) reported that delaying initial applications of pyraclostrobin as late as 60 DAP provided levels of leaf spot control equivalent to that of chlorothalonil or tebuconazole programs initiated at 30 DAP. Such results indicate that pyraclostrobin may be more suitable than chlorothalonil or tebuconazole when applications are late or delayed; however, fungicide resistance issues need to be addressed before such delays are implemented. One recommended fungicide program consists of an initial application of pyraclostrobin $\left(0.17 \mathrm{~kg}\right.$ a.i. ha $\left.{ }^{-1}\right)$ at 45 DAP followed by a second application of a compound with a different mode of action 21 days later. Subsequent applications of chlorothalonil or tebuconazole are made at 14-day intervals $(13,24)$.

An additional means of reducing the reliance on fungicides in the management of peanut diseases is the use of cultivars with increased disease resistance. The cv. Georgia Green is the current commercial standard and is planted on approximately $85 \%$ of the acreage in Georgia (Smith, personal 
communication). Currently, breeding programs in the southeast are focusing on developing resistance to Tomato spotted wilt virus (TSWV) but also are screening for resistance to both early and late leaf spot, Rhizoctonia limb rot, Cylindrocladium black rot (CBR), and stem rot. Cvs. Georgia-01R, Hull, and Tifrunner have been reported to possess the highest levels of leaf spot resistance commercially available $(4,8,20)$ whereas C-99R, AP-3, and Georgia-02C have moderate levels of stem rot resistance $(4,20,21,32)$. With the availability of cultivars possessing partial resistance to foliar and soilborne diseases, research is needed to evaluate the economic viability of reducing production inputs.

Another factor known to influence fungicide activity and disease pressure is irrigation (15). Approximately 55\% of peanut crops in Georgia are irrigated (Smith, personal communication) and most peanut disease research is done in intensively irrigated plots. There is a need for additional research on disease management and cultivar performance in irrigated versus nonirrigated fields. The first objective of these studies was to evaluate the performance of several commercially available peanut cultivars with different levels of resistance to several diseases under full and reduced fungicide programs. A second objective was to determine the effects of irrigation on disease development, cultivar performance, and fungicide efficacy.

\section{MATERIALS AND METHODS}

Cultivar experiment. This experiment was initiated in 2004 at the Rigdon Farm and repeated in 2005 at the Lang Farm, both being University of Georgia Coastal Plain Experiment Station (UGA-CPES) research sites located in Tifton. The soil type at both locations was a Tifton sandy loam. Both fields were nonirrigated and had a low to moderate leaf spot and stem rot risk according to the University of Georgia Fungal Disease Risk Index (28). The plot area in 2004 had been planted to cotton (Gossypium hirsutum L.) for more than 10 years and had no history of peanut production, whereas the field site chosen in 2005 had been part of a cotton-corn (Zea mays L.) rotation and had not been planted to peanut within the past 5 years. Fields were prepared for planting using a moldboard plow and a disk harrow. All production practices other than disease control were based on recommendations of the University of Georgia Cooperative Extension Service. Plots were two rows, $7.6 \mathrm{~m}$ long, planted $0.9 \mathrm{~m}$ apart, and seeded at a rate of 28 seeds $/ \mathrm{m}$ of row. Planting dates were 3 June 2004 and 12 May 2005. Eight commercially available runner-type cultivars were evaluated in both years of the experiment (Table 1). Cultivars were grouped by maturity (medium or late), as described by Gorbet et al. (21), and arranged in a split-plot design with five and four replications in 2004 and 2005, respectively. Whole-plot treatments consisted of fungicide programs and cultivars served as subplots. Broadcast applications of fungicide were made using a $\mathrm{CO}_{2}-$ pressurized backpack sprayer calibrated to deliver a total output of 188 liters ha $^{-1}$ with three TX-6 hollow-cone nozzles (TeeJet Technologies, Springfield, IL) per row.

Four fungicide programs were evaluated in these trials and included (i) a nontreated control; (ii) a leaf spot program consisting of seven applications of chlorothalonil (Bravo Ultrex; Syngenta Crop Protection, Greensboro, NC) at $1.26 \mathrm{~kg}$ a.i. ha ${ }^{-1}$; (iii) a full program consisting of pyraclostrobin (Headline 2.09 EC; BASF Corp., Research Triangle Park, NC) applied at a rate of $0.16 \mathrm{~kg}$ a.i. $\mathrm{ha}^{-1}$, followed by four applications of tebuconazole (Folicur 3.6F; Bayer Corp., Research Triangle Park, NC) at 0.23 $\mathrm{kg}$ a.i. ha ${ }^{-1}$, concluding with a single application of chlorothalonil; and (iv) a reduced program consisting of pyraclostrobin at $0.22 \mathrm{~kg}$ a.i. $\mathrm{ha}^{-1}$ and a single tebuconazole application. Details of specific timings of applications are given in Table 2.

Irrigation experiment. This experiment was conducted in 2004 and 2005 at the UGA-CPES Black Shank research farm in a field of Tifton loamy sand. The field was were designed to provide replicated irrigated and nonirrigated blocks. Supplemental irrigation was applied as needed to maximize peanut growth and maintain 6.4 $\mathrm{cm}$ of precipitation per week. The field site had been in continuous peanut production over the past 15 years, and was prepared and managed as described previously. Based on cultural practices, leaf spot and stem rot risk was considered high (28). Plots were two rows, $6.1 \mathrm{~m}$ long, $0.9 \mathrm{~m}$ apart, and planted on 25 May 2004 and 21 May 2005. Six cultivars (Georgia Green, Georgia-02C, Georgia-03L, Georgia-01R, Hull, and Tifrunner) were evaluated in this trial, representing medium and late maturirrigated with solid-set riser sprinklers that

ity groups. Cultivars were grouped by maturity as described by Gorbet et al. (21). Plots were arranged in a split-split-plot design with five replications. Fungicide programs served as whole plots, irrigation as subplots, and cultivar as sub-subplots. Two fungicide programs, designated standard and reduced-input, were evaluated in this experiment. Broadcast applications were applied as described above. The application schedule for the standard program was similar to the full pyraclostrobin-four-block-tebuconazole program listed above, except that azoxystrobin at $0.34 \mathrm{~kg}$ a.i. ha ${ }^{-1}$ (Abound 2.08SC; Syngenta Crop Protection) replaced the final tebuconazole application. The reducedinput program derived from this program consisted of pyraclostrobin applied 40 DAP, tebuconazole applications 61 and 82 DAP, and a single application of azoxystrobin replacing the final tebuconazole application (Table 2).

Disease assessment. Early and late leaf spot were assessed for each plot using the Florida 1-to-10 scale, a disease index where $1=$ no disease; 2 = very few lesions (none on upper canopy); 3 = few lesions (very few on upper canopy); $4=$ upper canopy with noticeable $(<5 \%)$ defoliation; $5=$ lesions present on upper canopy, with noticeable (approximately 20\%) defoliation; $6=$ lesions numerous and very evident on upper canopy, with significant (approximately 50\%) defoliation, $7=$ lesions numerous on upper canopy, with much (approximately 75\%) defoliation; 8 $=$ upper canopy covered with lesions and high (approximately 90\%) defoliation; $9=$ very few leaves remaining and those covered with lesions (some plants $100 \%$ defoliated); and $10=$ plants completely defoliated by leaf spot (9). Disease was assessed at the onset of epidemics and subsequent assessments were made every 14 to 21 days until harvest. Leaf spot assessments were used to calculate the area under disease progress curve (AUDPC) for each

Table 1. Disease resistance, seeding rate, seed count, and costs of seed of medium- and late-maturing peanut cultivars used in studies evaluating reduced-input fungicide programs

\section{Resistance levely}

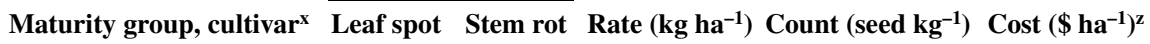

Medium

\begin{tabular}{|c|c|c|c|c|c|}
\hline \multicolumn{6}{|l|}{ Medium } \\
\hline Georgia Green & $\mathrm{S}$ & $\mathrm{S}$ & 109 & 1,972 & 125.35 \\
\hline Georgia-02C & I & $\mathrm{R}$ & 120 & 1,794 & 138.00 \\
\hline Georgia-03L & I & $\mathrm{R}$ & 132 & 1,628 & 151.80 \\
\hline AP-3 & $\mathrm{S}$ & $\mathrm{R}$ & 122 & 1,767 & 140.30 \\
\hline \multicolumn{6}{|l|}{ Late } \\
\hline Georgia-01R & $\mathrm{R}$ & I & 132 & 1,628 & 151.80 \\
\hline C-99R & I & I & 133 & 1,625 & 152.95 \\
\hline Hull & $\mathrm{R}$ & I & 128 & 1,677 & 147.20 \\
\hline Tifrunner & $\mathrm{R}$ & $\mathrm{S}$ & 125 & 1,727 & 143.75 \\
\hline
\end{tabular}

x Approximate days from planting to maturity for medium and late maturity groups were 135 to 140 and 155 to 160 , respectively.

${ }^{y}$ Disease resistance levels are based on the University of Georgia Fungal Disease Risk Index (28). Cultivars which exhibit a susceptible, resistant, or intermediate reaction to leaf spot or stem rot are denoted with $\mathrm{S}, \mathrm{R}$, or I, respectively.

z Total seed costs were determined using methods described by Cantonwine et al. (8), using an average cost of $\$ 1.15 \mathrm{~kg}^{-1}$. 
plot (35). To account for differences in the duration of leaf spot epidemics between cultivars, AUDPC values were standardized (stAUDPC) by dividing by the duration of the epidemic in days. Spotted wilt intensity was evaluated once at 75 to 90 DAP, and converted to a percentage of row length (14).

Plots were dug and inverted based on pod maturity determined by the hull scrape method (41). Incidence of stem rot was estimated immediately after plants were inverted by determining the number of disease loci per plot $(<30 \mathrm{~cm}$ per locus $)$ exhibiting stem rot symptoms or signs of $S$. rolfsii (34). The number of disease loci within a plot was converted to a percentage of total row length for comparison of treatments.

Pod yield, quality, and economic returns. Pod yields were determined for each plot by weighing harvested pods after they were dried, and adjusted to $10 \%$ moisture (wt/wt). A 500-g subsample of pods was collected from each plot and graded according to the 2005 Federal Inspection Service (38). The dollar values of pod yields were determined for each plot based on the percentages of foreign material $(\% \mathrm{FM})$, total sound mature kernels (\%TSMK), damaged kernels (\%DK), and other kernels (\%OK) using the 2005 United States Department of Agriculture loan price schedules $(39,40)$. Crop values were calculated for each plot based on the 2004 pod price schedule, where dollars $/$ metric ton $=([(\%$ TSMK $\times \$ 5.02)+$ $(\% \mathrm{OK} \times \$ 1.57)]-[(\% \mathrm{FM}-4) \times \$ 1.12]-$ (\%DK deduction)). Deductions of $\$ 0.00$, $\$ 3.80$, and $\$ 7.60 /$ metric ton were assessed for DK percentages of $\leq 2, \leq 3$, and $\leq 4$, respectively (40).

Variable costs, including machinery use, were based on University of Georgia enterprise budgets (37) utilizing an estimated fuel price of $\$ 0.60$ liter $^{-1}$ and a labor wage of $\$ 9.05 \mathrm{~h}^{-1}$. Adjustments were made to account for differences in seed and fungicide costs. Seed costs (Table 1) were estimated as described by Cantonwine et al. (8), and the seed weight was determined for each cultivar using a 3-year average (2003 to 2005) of irrigated trials conducted by the University of Georgia State Wide Variety Testing Program (16-18). Fungicide costs were estimated based on prices obtained from a survey of pesticide distributors located throughout the state (Table 2). Additional adjustments were made to account for energy costs required to apply irrigation. The economic analysis was conducted using a budgeting technique consistent with University of Georgia Cooperative Extension cost enterprise budgets. A plot generator spreadsheet tool (Smith, personal communication) was modified to run cost and returns for each plot. Economic returns, defined as the income above variable cost (IAVC), were calculated as the difference between variable costs and the estimated crop value based on $\$ 398 /$ metric ton and adjusted for grade according to the 2005 Crop Peanut Loan Rates $(39,40)$.

Statistical analysis. Data were analyzed using Proc MIXED (SAS v.9.1; SAS Institute, Cary, NC) with the ddfm=satterthwaite option in the model statement and treatment comparisons based on LSMEANS with the pdiff option. Because leaf spot intensity values were based on ordinal-categorical data, ranked analyses were used to equalize variances. For leaf spot intensity and stAUDPC data, Proc RANK was used to assign ranks using midrank for any ties, and Proc MIXED was used to analyze the rank-transformed data from the cultivar and irrigation experiments. For the cultivar experiment, fixed effects included fungicide program
(FP), cultivar (C), and $\mathrm{FP}-\mathrm{C}$ interaction, while random effects included year $(\mathrm{Y})$, replication (R[Y]), and $\mathrm{R}-\mathrm{FP}(\mathrm{Y})$. For the irrigation experiment, fixed effects included FP, irrigation (I), Cultivar [C], FP$\mathrm{I}, \mathrm{FP}-\mathrm{C}$, I-C, and $\mathrm{FP}-\mathrm{I}-\mathrm{C}$, while random effects included $\mathrm{Y}, \mathrm{R}(\mathrm{Y}), \mathrm{R}-\mathrm{FP}(\mathrm{Y})$, and R$\mathrm{I}(\mathrm{YI})$. Fixed effects were considered significant at the $P=0.05$ unless otherwise stated. Least square means of treatments were compared using the Pdiff options in the LSMEANS statement of Proc MIXED, and least significant difference (LSD) values were calculated using the standard errors and $t$ values representing the adjusted degrees of freedom. When interactions were significant, the LSD for main effects was further adjusted by including the interaction in the random statement as suggested by Fisher (19) and elaborated by Cantonwine et al. (8).

\section{RESULTS}

Cultivar experiment. Leaf spot epidemics were severe and late leaf spot was the predominant leaf spot disease at harvest in both years of this experiment. Due to a lack of any significant interactions, leaf spot data were pooled across years. Significant differences were observed among both cultivars and fungicide programs (Table 3). Overall, stAUDPC values were similar for the medium- and latematuring cultivars. For each cultivar, all fungicide programs significantly reduced the stAUDPC compared with the nontreated control. There were no significant differences between the standard leaf spot program and the full pyraclostrobin program, which had lower stAUDPC values than the reduced pyraclostrobin program.

No significant interactions were observed with regard to spotted wilt; therefore, data were pooled for analysis. Dis-

Table 2. Characteristics and costs of full- and reduced-input fungicide programs for peanut disease control in two field studies

\begin{tabular}{|c|c|c|c|c|c|}
\hline Experiment, program & Fungicide & Formulationw & Rate $\left(\mathrm{kg} \text { a.i. } \mathrm{ha}^{-1}\right)^{\mathrm{x}}$ & Schedule $^{y}$ & Cost $\left(\$ h a^{-1}\right)^{z}$ \\
\hline \multicolumn{6}{|l|}{ Cultivar } \\
\hline Control & None & & & & 0.00 \\
\hline Leaf spot & Chlorothalonil & Bravo Ultrex 82.5WDG & 1.26 & $1-7$ & 135.31 \\
\hline \multirow[t]{3}{*}{ Full-input } & Pyraclostrobin & Headline 2.09EC & 0.16 & 1.5 & 193.11 \\
\hline & Tebuconazole & Folicur 3.6F & 0.23 & $3-6$ & $\ldots$ \\
\hline & Chlorothalonil & Bravo Ultrex $82.5 \mathrm{WDG}$ & 1.26 & 7 & $\ldots$ \\
\hline \multirow[t]{2}{*}{ Reduced program } & Pyraclostrobin & Headline 2.09EC & 0.22 & 3 & 81.34 \\
\hline & Tebuconazole & Folicur 3.6F & 0.23 & 5 & $\ldots$ \\
\hline \multicolumn{6}{|l|}{ Irrigation } \\
\hline \multirow[t]{4}{*}{ Full program } & Pyraclostrobin & Headline $2.09 \mathrm{EC}$ & 0.16 & 1.5 & 230.60 \\
\hline & Tebuconazole & Folicur 3.6F & 0.23 & $3-5$ & $\ldots$ \\
\hline & Azoxystrobin & Abound $2.08 \mathrm{~F}$ & 0.34 & 6 & $\ldots$ \\
\hline & Chlorothalonil & Bravo Ultrex $82.5 \mathrm{WDG}$ & 1.26 & 7 & $\ldots$ \\
\hline \multirow[t]{3}{*}{ Reduced program } & Pyraclostrobin & Headline 2.09EC & 0.16 & 1.5 & 176.57 \\
\hline & Tebuconazole & Folicur 3.6F & 0.23 & 3 and 4.5 & $\ldots$ \\
\hline & Azoxystrobin & Abound $2.08 \mathrm{~F}$ & 0.34 & 6 & $\ldots$ \\
\hline
\end{tabular}

${ }^{\text {w }}$ Percentage of a.i. in products formulated as water-dispersed granules (WDG), emulsifiable concentrates (EC), or flowables (F).

${ }^{\mathrm{x}}$ Fungicide application rate.

${ }^{y}$ Represents sprays in a standard seven-spray schedule (i.e., there is 1 week between 1 and 1.5 and 2 weeks between 1 and 2). Initial applications were made approximately 30 days after planting.

${ }^{\mathrm{z}}$ Fungicide program costs were based on results from a regional survey: chlorothalonil $\left(\$ 19.33 \mathrm{ha}^{-1}\right)$; tebuconazole $\left(\$ 34.70 \mathrm{ha}^{-1}\right)$; azoxystrobin $\left(\$ 72.19 \mathrm{ha}^{-1}\right)$; and pyraclostrobin ( $\$ 34.98$ and $\$ 46.64 \mathrm{ha}^{-1}$ for the 0.17 and $0.25 \mathrm{~kg}$ a.i. rates, respectively). 
ease incidence was low in 2004 but high in 2005, and differences in cultivar response to spotted wilt were significant (Table 3). Disease incidence was greatest for Georgia Green, Hull, and C-99R and lowest for AP-3, Georgia-03L, and Georgia-02C. Disease incidence was intermediate for Tifrunner and Georgia-01R. There were no significant differences in spotted wilt incidence among fungicide programs.

Fungicide and cultivar main effects, as well as the fungicide-cultivar interaction, were significant for stem rot; therefore, cultivars were compared within each fungicide program (Fig. 1). Disease severity generally was lowest in plots that received the full-input program and highest in the nontreated plot. Some general patterns of cultivar susceptibility were observed. Final incidence of stem rot was highest for Tifrunner and lowest for Georgia-03L, Georgia-02C, and AP-3. In general, stem rot incidence was lower when fungicides, including the standard leaf spot program, were applied. The mean final disease incidence across cultivars was $32.4,19.3,14.1$, and $21.8 \%$ for the nontreated, standard leaf spot, and full- and reduced-input pyraclostrobin programs, respectively.

No significant interactions were observed for pod yields; therefore, data were pooled. Pod yields of all other cultivars were equivalent to or greater than yields for Georgia Green, the current industry standard (Table 3). Cv. AP-3 had the highest yields, followed by Georgia-01R, C99R, and Georgia-03L. Yields were significantly higher in plots that received fungicide treatments compared with the nontreated controls (Table 3 ). The standard leaf spot and full-input pyraclostrobin programs resulted in the highest yields, whereas pod yields for the reduced-input pyraclostrobin program were intermediate. Significant differences in pod quality were observed among cultivars. AP-3 and Georgia-03L had the lowest pod quality, whereas C-99R, Georgia Green, Georgia-
$02 \mathrm{C}$, and Georgia-01R were among the cultivars with the highest quality (Table 3 ). There was no significant fungicide effect on pod quality either year. Overall, the mean percent immature kernels ranged from 9.5 to $17.6 \%$ and the mean $\% \mathrm{FM}$ and
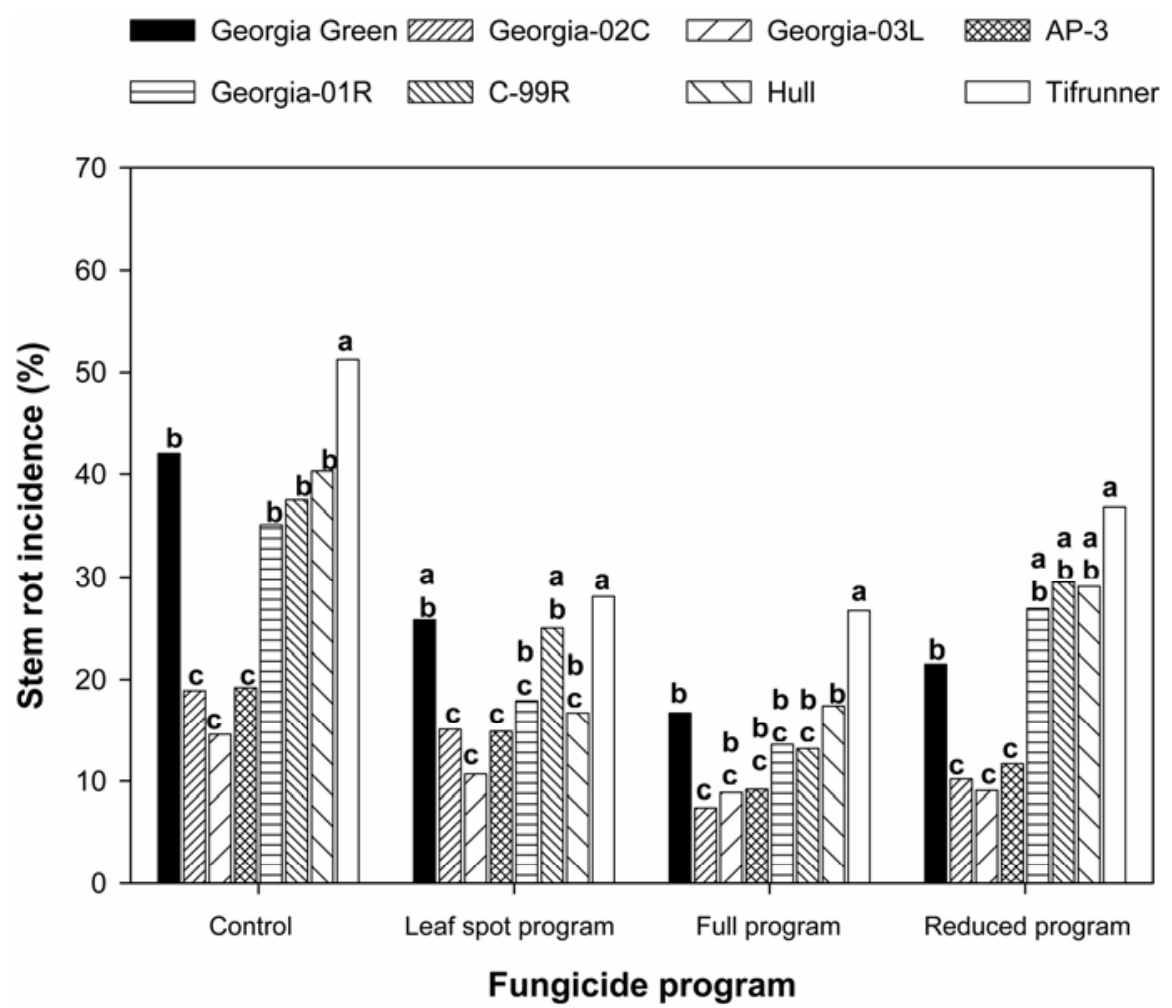

Fig. 1. Effect of peanut cultivar and fungicide program interaction on stem rot incidence across 2 years. Fisher's least significant difference values were calculated using the standard errors and $t$ values representing the adjusted degrees of freedom from the pairwise comparison of least square means. Means represented by bars marked with the same letter are not significantly different $(P=0.05)$ within a fungicide program $(n=9)$. (Refer to footnote $\mathrm{x}$ on Table 4 for the determination of means separation letters shown above).

Table 3. Effect of peanut cultivar, fungicide program, and irrigation on leaf spot, spotted wilt, yield, quality, and returns (cultivar experiment $)^{t}$

\begin{tabular}{|c|c|c|c|c|c|c|}
\hline Effect & $n$ & $\begin{array}{c}\text { Leaf spot } \\
\text { (stAUDPC) }^{\mathrm{u}}\end{array}$ & $\begin{array}{c}\text { Spotted wilt } \\
\text { incidence }(\%)^{\mathrm{v}}\end{array}$ & $\begin{array}{l}\text { Pod yield } \\
\left(\mathrm{kg} \mathrm{ha}^{-1}\right)^{\mathrm{w}}\end{array}$ & $\begin{array}{l}\text { Pod quality } \\
(\% \text { TSMK) }\end{array}$ & $\begin{array}{l}\text { Return } \\
\left(\$ \mathbf{h a}^{-1}\right)^{\mathrm{y}}\end{array}$ \\
\hline \multicolumn{7}{|l|}{ Cultivar } \\
\hline Georgia Green & 36 & $3.38 \mathrm{ab}$ & $34.2 \mathrm{a}$ & $3,389 \mathrm{~b}$ & $70.6 \mathrm{ab}$ & $539 \mathrm{bcd}$ \\
\hline Georgia-02C & 36 & $3.43 \mathrm{a}$ & $15.4 \mathrm{bc}$ & $3,768 \mathrm{ab}$ & $71.5 \mathrm{a}$ & $550 \mathrm{bcd}$ \\
\hline Georgia-03L & 36 & $2.58 \mathrm{~b}$ & $11.6 \mathrm{c}$ & $3,817 \mathrm{ab}$ & $68.3 \mathrm{c}$ & $544 \mathrm{bcd}$ \\
\hline AP-3 & 36 & $2.76 \mathrm{ab}$ & $10.8 \mathrm{c}$ & $4,485 \mathrm{a}$ & $67.5 \mathrm{c}$ & $837 \mathrm{a}$ \\
\hline Georgia-01R & 36 & $2.87 \mathrm{ab}$ & $22.7 \mathrm{abc}$ & $4,251 \mathrm{ab}$ & $72.2 \mathrm{a}$ & $690 \mathrm{bc}$ \\
\hline C-99R & 36 & $3.05 \mathrm{a}$ & $30.7 \mathrm{ab}$ & $4,027 \mathrm{ab}$ & $71.9 \mathrm{a}$ & $668 \mathrm{bcd}$ \\
\hline Hull & 36 & $2.93 \mathrm{ab}$ & $30.0 \mathrm{ab}$ & $3,628 \mathrm{ab}$ & $69.0 \mathrm{bc}$ & $562 \mathrm{bcd}$ \\
\hline Tifrunner & 36 & $3.17 \mathrm{ab}$ & $17.2 \mathrm{abc}$ & $3,742 \mathrm{ab}$ & $70.8 \mathrm{ab}$ & $493 \mathrm{~d}$ \\
\hline \multicolumn{7}{|l|}{ Fungicide program ${ }^{\mathrm{z}}$} \\
\hline Nontreated control & 72 & $4.26 \mathrm{a}$ & $19.3 \mathrm{a}$ & $3,132 \mathrm{~b}$ & $70.5 \mathrm{a}$ & $337 \mathrm{c}$ \\
\hline Leaf spot program & 72 & $2.17 \mathrm{c}$ & $23.0 \mathrm{a}$ & $4,361 \mathrm{a}$ & $70.2 \mathrm{a}$ & 821 a \\
\hline Full program & 72 & $2.56 \mathrm{c}$ & $21.2 \mathrm{a}$ & $4,368 \mathrm{a}$ & $69.8 \mathrm{a}$ & $785 \mathrm{a}$ \\
\hline Reduced program & 72 & $3.09 \mathrm{~b}$ & $22.9 \mathrm{a}$ & $3,694 a b$ & $70.5 \mathrm{a}$ & $498 \mathrm{~b}$ \\
\hline
\end{tabular}

\footnotetext{
${ }^{t}$ Data are from combined analysis across 2 years. Fishers least significant difference values were calculated using the standard errors and $t$ values representing the adjusted degrees of freedom from the pairwise comparison of least square means. Means followed by the same letter are not significantly different at the $P=0.05$ level.

${ }^{u}$ Least square means from Proc MIXED of standardized area under disease progress curve (stAUDPC) using Florida 1-to-10 leaf spot intensity ratings (9). Values were standardized by dividing by the duration (number of days) of the epidemic.

${ }^{\mathrm{v}}$ Least square means from Proc MIXED of percent linear row affected by spotted wilt.

${ }^{\mathrm{w}}$ Least square means from Proc MIXED of estimated weights of peanut pods per hectare after drying to $10 \%$ moisture (wt/wt).

${ }^{\mathrm{x}}$ Least square means from Proc MIXED of percent yield weight of total sound mature kernels (TSMK).

${ }^{y}$ Least square means from Proc MIXED of estimated crop value. Means represent the income above variable cost (IAVC) and were calculated using the 2005 peanut pod price schedule minus variable cost of production.

${ }^{\mathrm{z}}$ For a detailed description of fungicide programs, see Table 2.
} 
\%DK were below deduction thresholds (data not shown).

Fungicide program costs (Table 2) and seed costs of each cultivar (Table 1) were included in variable costs and return calculations. Cultivar and fungicide program had significant effects on economic returns (Table 3). Mean returns ranged from $\$ 837$ for AP-3 to $\$ 493 \mathrm{ha}^{-1}$ for Tifrunner. All other cultivars except Georgia-01R had returns equivalent to Tifrunner. The application of fungicides resulted in significantly greater returns compared with the nontreated control; however, returns for the reduced-input program were significantly less than the leaf spot or full-input program for all cultivars.

Irrigation experiment. Stem rot epidemics were similar during both years of the experiment and were severe at harvest, ranging from 19.8 to $68.0 \%$. A significant fungicide-cultivar interaction was observed for stem rot incidence. Significant differences in disease development were observed between cultivars under each fungicide program (Table 4). Incidence of stem rot generally was greatest for cvs. Georgia Green and Tifrunner and lowest for cvs. Georgia-03L and Georgia-02C. Stem rot incidence was numerically greater for the reduced-input programs; however, the differences were not statistically significant. Additionally, there were no significant irrigation effects on stem rot or leaf spot development.

There were no significant interaction effects between fungicide programs and cultivar on leaf spot intensity, spotted wilt

Table 4. Effect of peanut cultivar and fungicide program on stem rot incidence and economic returns across irrigation treatments

\begin{tabular}{|c|c|c|c|c|}
\hline \multirow[b]{3}{*}{ Cultivar } & \multicolumn{4}{|c|}{ Programs $^{x}$} \\
\hline & \multicolumn{2}{|c|}{ Stem rot incidence $(\%)^{\mathrm{y}}$} & \multicolumn{2}{|c|}{$\operatorname{Return}\left(\$ h^{-1}\right)^{z}$} \\
\hline & Full & Reduced & Full & Reduced \\
\hline Georgia Green & $58.8 \mathrm{a}$ & $67.4 \mathrm{a}$ & $187 \mathrm{bc}$ & $135 \mathrm{bc}$ \\
\hline Georgia-02C & $26.1 \mathrm{bc}$ & $36.4 \mathrm{bc}$ & $223 a b c$ & $214 \mathrm{a}$ \\
\hline Georgia-03L & $19.8 \mathrm{c}$ & $27.3 \mathrm{c}$ & $235 \mathrm{ab}$ & $244 \mathrm{a}$ \\
\hline Georgia-01R & $24.9 \mathrm{bc}$ & $41.6 \mathrm{abc}$ & $240 \mathrm{ab}$ & $149 \mathrm{~b}$ \\
\hline Hull & $37.1 \mathrm{abc}$ & $57.3 \mathrm{ab}$ & $174 \mathrm{c}$ & $39 \mathrm{~d}$ \\
\hline Tifrunner & $50.9 \mathrm{ab}$ & $68.0 \mathrm{a}$ & $271 \mathrm{a}$ & $92 \mathrm{~cd}$ \\
\hline
\end{tabular}

${ }^{\mathrm{x}}$ For a detailed description of fungicide programs, see Table 2. Least significant difference was calculated using the standard errors from the PDIFF option in Proc MIXED and $t$ values from the Satterthwaite adjusted degrees of freedom from the pairwise comparison of least square means (also in PDIFF option). Means followed by the same letter within a variable are not significantly different at the $P=0.05$ level.

${ }^{y}$ Least square means from Proc MIXED of percentage of $30.5-\mathrm{cm}$ row segments showing signs or symptoms of Sclerotium rolfsii infection (34).

${ }^{\mathrm{z}}$ Least square means from Proc MIXED of estimated crop value. Means represent the income above variable cost (IAVC) and were calculated using the 2005 peanut pod price schedule minus variable cost of production.

Table 5. Effect of peanut cultivar, fungicide program, and irrigation on leaf spot development, spotted wilt incidence, peanut yield, and quality ${ }^{\mathrm{v}}$

\begin{tabular}{|c|c|c|c|c|}
\hline Effect & $\begin{array}{c}\text { Leaf spot } \\
\text { (stAUDPC) }^{w}\end{array}$ & $\begin{array}{c}\text { Spotted wilt } \\
\text { incidence }(\%)^{x}\end{array}$ & $\begin{array}{l}\text { Pod yield } \\
\left(\mathrm{kg} \mathrm{ha}^{-1}\right)^{\mathrm{y}}\end{array}$ & $\begin{array}{l}\text { Pod quality } \\
(\% \text { TSMK) }\end{array}$ \\
\hline \multicolumn{5}{|l|}{ Cultivar } \\
\hline Georgia Green & $1.97 \mathrm{a}$ & $28.9 \mathrm{a}$ & $4,313 b c$ & $73.2 \mathrm{a}$ \\
\hline Georgia-02C & $1.87 \mathrm{a}$ & $17.8 \mathrm{bc}$ & $4,785 a b$ & $72.7 \mathrm{a}$ \\
\hline Georgia-03L & $1.61 \mathrm{ab}$ & $16.3 \mathrm{c}$ & $5,197 \mathrm{a}$ & $71.1 \mathrm{a}$ \\
\hline Georgia-01R & $1.43 \mathrm{~b}$ & $24.5 \mathrm{abc}$ & $4,661 \mathrm{bc}$ & $72.7 \mathrm{a}$ \\
\hline Hull & $1.51 \mathrm{~b}$ & $28.4 \mathrm{ab}$ & $3,942 \mathrm{c}$ & $71.7 \mathrm{a}$ \\
\hline Tifrunner & $1.71 \mathrm{ab}$ & $14.6 \mathrm{c}$ & $4,549 a b c$ & $72.0 \mathrm{a}$ \\
\hline \multicolumn{5}{|c|}{ Fungicide program } \\
\hline Full-input & $1.47 \mathrm{a}$ & $20.9 \mathrm{a}$ & $4,967 \mathrm{a}$ & $72.0 \mathrm{a}$ \\
\hline Reduced-input & $1.90 \mathrm{a}$ & $22.5 \mathrm{a}$ & $4,174 \mathrm{a}$ & $72.5 \mathrm{a}$ \\
\hline \multicolumn{5}{|l|}{ Irrigation } \\
\hline Irrigated & $1.81 \mathrm{a}$ & $23.1 \mathrm{a}$ & $4,473 \mathrm{a}$ & $72.4 \mathrm{a}$ \\
\hline Nonirrigated & $1.55 \mathrm{a}$ & $20.3 \mathrm{a}$ & $4,669 \mathrm{a}$ & $72.1 \mathrm{a}$ \\
\hline
\end{tabular}

${ }^{\mathrm{v}}$ Least significant differences were calculated using the standard errors and $t$ values from the adjusted degrees of freedom from the pairwise comparison of LSMEANS. Means followed by the same letter are not significantly different at the $P=0.05$ level.

${ }^{\mathrm{w}}$ Least square means from Proc MIXED of standardized area under disease progress curve (stAUDPC) using Florida 1-to-10 leaf spot intensity ratings (9). Epidemics were standardized by dividing by the duration (number of days) of the epidemic.

${ }^{x}$ Least square means from Proc MIXED of percent linear row affected by spotted wilt.

${ }^{y}$ Least square means from Proc MIXED of estimated weights of peanut pods per hectare after drying to $10 \%$ moisture (wt/wt)

${ }^{\mathrm{z}}$ Least square means from Proc MIXED of percent yield weight of total sound mature kernels (TSMK). incidence, pod yield, grade, or economic returns; therefore, only main effects are presented (Table 5). Of the main effects tested, only cultivar had a significant effect on stAUDPC. Early leaf spot was the predominant foliar disease throughout each of the growing seasons; however, late leaf spot became more prevalent at the time of harvest in both years. The stAUDPC values were similar for the three medium maturing cultivars, and values for Georgia03L did not differ from Georgia-01R, Hull, or Tifrunner. In addition, only cultivar had a significant effect on spotted wilt incidence. Spotted wilt was more severe in 2004 than in 2005; however, cultivar effects were similar both years. Disease incidence was lowest for Tifrunner, Georgia-03L, and Georgia-02C and greatest for Georgia Green, Georgia-01R, and Hull. Cultivar, fungicide, and irrigation treatments had no significant effect on pod quality. The mean percentages of TSMK, immature kernels, and FM were 72.2, 2.7, 2.8 , and 0.8 , respectively.

There was a significant fungicidecultivar interaction for economic returns. Significant differences in returns were observed between cultivars under each fungicide program. The cost of the fullinput program was $\$ 230.60 \mathrm{ha}^{-1}$ compared with $\$ 176.57 \mathrm{ha}^{-1}$ for the reduced-input program (Table 2). For the full-input program, returns were greatest for cvs. Tifrunner, Georgia-03L, and Georgia-01R (Table 4). Likewise, returns for the reduced-input program were greatest for Georgia-03L and Georgia-02C; however, Tifrunner and Georgia-01R did not perform as well under the reduced-input program. The number of irrigation events varied by year. In all, five applications were made in 2004 and nine applications in 2005. Based on current energy prices, the estimated cost associated with each irrigation event was $\$ 19.41 \mathrm{ha}^{-1}$, resulting in costs of $\$ 97.04 \mathrm{ha}^{-1}$ and $\$ 174.67 \mathrm{ha}^{-1}$ for 2004 and 2005, respectively.

\section{DISCUSSION}

The availability of peanut cultivars with moderate levels of disease resistance has made it possible to manage diseases with reduced fungicide inputs $(1,3,8,12,13$, 22,32 ), which potentially can reduce costs and increase profits for producers. In addition, fungicide programs containing pyraclostrobin have been shown to provide levels of leaf spot control superior to that of chlorothalonil $(10,13,24,25)$, and delaying initial applications of pyraclostrobin until 44 DAP has been shown to provide levels of leaf spot control similar to chlorothalonil or tebuconazole applications made 30 DAP (13). The flexibility of delaying initial applications of pyraclostrobin without compromising leaf spot control allows producers to reduce the number of fungicide applications and associated costs. However; the risk of resistance to 
strobilurin fungicides must be considered. Current guidelines for use of QoI fungicides in peanut discourage curative applications and limit growers to two applications per season (7).

Leaf spot levels differed between the standard- and reduced-input programs in the cultivar experiment but not the irrigation experiment of this study. This was unexpected based on rotational and cropping histories of the locations. According to the University of Georgia Fungal Disease Risk Index (28), disease risk was determined to be low to moderate for the cultivar experiment, whereas the irrigation studies were deemed as high risk. One explanation of the performance in the reduced programs in the cultivar experiment could be attributed to SBI-insensitive isolates of $C$. personatum at the locations where these experiments were conducted. Concerns over SBI resistance have been expressed (2), and recent studies have shown reduced efficacy of tebuconazole (11). SBI-insensitive isolates of both leaf spot pathogens were recovered from the cultivar experiment in 2005 (Stevenson, personal communication). The reduced control of leaf spot in these studies did affect yield and, as a result, economic returns were impacted. However, the reduced program proved to be valuable in managing diseases when compared with the nontreated control.

Results from these studies corroborate previous reports that the cultivars evaluated have yields that are equivalent to or greater than yields for Georgia Green $(8,16-18,20,21,32)$. Increased yields could be attributed to the yield potential of each cultivar or to increased resistance to spotted wilt, leaf spot, or stem rot, which limited yields of Georgia Green. In both the cultivar and the irrigation studies, yields were highest for the cultivars with increased stem rot resistance. Yields were similar across the two maturity groups. Medium-maturing cultivars with the highest yield were AP-3 and Georgia-03L from the cultivar and irrigation experiments, respectively, whereas Georgia-01R had the highest yields for the late-maturing cultivars in both studies. The use of cultivars with increased disease resistance will play an important role when implementing reduced-input fungicide programs.

Although pyraclostrobin is labeled for control of stem rot, reports of its efficacy are inconclusive $(13,24)$. When determining which fungicides to use in a regime, considerations for stem rot control are critical. Other studies have shown that programs containing fungicides with activity against soilborne diseases provide significantly higher yields than foliar-based programs $(3,5,6,24,25)$. However, the majority of those studies were conducted using moderately susceptible cultivars in fields with high soilborne disease pressure. Reduced-input foliar-based programs were not evaluated in these studies. Such programs would not be warranted in fields with continuous peanut and a history of disease, as was the case for the field where the irrigation experiments were conducted, but may be appropriate in fields deemed as having reduced risk, as was the case in the cultivar experiment. In that experiment, a full-season chlorothalonil program also was evaluated because of the low risk of stem rot. The seven-spray foliar program provided sufficient control of leaf spot and is relatively inexpensive compared with applications for soilborne disease control; therefore, the leaf spot program also provided the highest economic returns. Additional studies evaluating reduced-input chlorothalonil programs may be needed to elucidate which programs will allow producers to maximize profits when using stem-rot-resistant cultivars in low-risk fields.

Precipitation is also an important factor in maximizing yields, and one would expect to have increased yields in fields receiving irrigation $(15,30)$. However, that was not the case for the irrigation experiment. Economic returns were significantly higher for nonirrigated plots compared with irrigated plots. These trends are somewhat atypical and can be explained by rainfall amounts that were substantially higher than the 10-year average for the region (26) in 2004 and early during the 2005 season; however, supplemental irrigation was applied during 2005 to avoid drought stress. Levels of leaf spot and stem rot, as well as yield, were similar in irrigated plots compared with nonirrigated plots.

The cultivars evaluated in the irrigation experiment performed similarly to those in the cultivar experiment with respect to disease susceptibility. No significant differences in economic returns were found between the two fungicide programs when analyzed across all cultivars; however, returns for the reduced program for cultivars deemed as being resistant to stem rot were closer to returns obtained from using the full program. Returns for the reduced program were lower than for the full program with late-maturing cultivars. This decrease in economic returns could be related to the duration of leaf spot and stem rot epidemics. Fungicide programs were initiated at the same time for all cultivars; however, the late-maturing cultivars remained in the field 4 weeks or later without receiving any additional fungicide applications. Despite improved levels of resistance for Georgia-01R and Hull, final leaf spot and stem rot levels were substantially higher than the final assessments of the medium-maturing cultivars. This trend was most evident for Tifrunner, which is highly susceptible to stem rot infection (28). Studies evaluating the initiation of spray programs for later-maturing cultivars are needed.
By using the Fungal Disease Risk Index (28), producers can estimate the level of disease risk within a field and make adjustments to fungicide programs accordingly. Results from these experiments indicate that cultivars with increased stem rot resistance can be used in conjunction with reduced-input fungicide programs to maximize profits. Results from the irrigation experiment, in particular, lend credence to the use of reduced-input fungicide programs in conjunction with diseaseresistant cultivars. Additional experiments examining reduced-input fungicide programs are warranted, as is the evaluation of fungicide tank mixes to combat fungicide resistance issues, thus prolonging the use of products currently available.

\section{ACKNOWLEDGMENTS}

This project was funded in part by Georgia peanut growers through grants from the Georgia Agricultural Commodity Commission for Peanuts. We thank L. Mullis, J. Mixon, D. Hickey, and P. Hilton for technical assistance; and B. Mullinix for statistical analysis.

\section{LITERATURE CITED}

1. Besler, B. A., Grichar, W. J., Smith, O. D., and Jaks, A. J. 2001. Response of peanut cultivars to full and reduced spray programs of tebuconazole for control of southern stem rot. Peanut Sci. 28:5-8.

2. Bowen, K. L., Hagan, A. K., and Weeks, J. R. 1997. Number of tebuconazole applications for maximizing disease control and yield of peanut in grower's fields in Alabama. Plant Dis. 81:927-931.

3. Brenneman, T. B., and Culbreath, A. K. 1994 Utilizing a sterol demethylation inhibiting fungicide in an advisory program to manage foliar and soilborne pathogens of peanut. Plant Dis. 78:866-872.

4. Brenneman, T. B., Culbreath, A. K., and Holbrook, C. C. 2005. Screening cultivars and advanced germplasm for multiple disease resistance. (Abstr.) Proc. Am. Peanut Res. Educ. Soc. 37:30

5. Brenneman, T. B., and Murphy, A. P. 1991. Activity of tebuconazole on Cercosporidium personatum, a foliar pathogen of peanut. Plant Dis. 75:699-703.

6. Brenneman, T. B., Murphy, A. P., and Csinos, A. S. 1991. Activity of tebuconazole on Sclerotium rolfsii and Rhizoctonia solani, two soilborne pathogens of peanut. Plant Dis. 75:744747.

7. Brent, K. J., and Hooloman, D. L. 1998. Fungicide resistance: the assessment of risk. In: Fungicide Resistance Action Committee Monograph No. 2. Global Crop Federation, Brussels.

8. Cantonwine, E. G., Culbreath, A. K., Stevenson, K. L., Kemerait, R. C., Jr., Brenneman, T. B., Smith, N. B., and Mullinix, B. G., Jr. 2005. Integrated disease management of leaf spot and spotted wilt of peanut. Plant Dis. 90:493500 .

9. Chiketa, Z. A., Gorbet, D. W., Shokes. F. M., Kucharek, T. A., and Knauft, D. A. 1988. Components of resistance to late leaf spot in peanut I. Levels of variability-implications for selection. Peanut Sci. 15:25-30.

10. Culbreath, A. K., Brenneman, T. B., and Kemerait, R. C., Jr. 2002. Management of early leaf spot of peanut with pyraclostrobin as affected by rate and spray interval. Online. Plant Health Progress doi:10.1094/PHP-20021018-01-RS.

11. Culbreath, A. K., Brenneman, T. B., Kemerait, 
R. C., and Stevenson, K. L. 2005. Relative performance of tebuconazole and chlorothalonil for control of peanut leaf spot from 1994 to 2004. (Abstr.) Proc. Am. Peanut Res. Educ. Soc. 37:54

12. Culbreath, A. K., Brenneman, T. B., and Kvien, C. K. 1992. Use of a resistant peanut cultivar with copper fungicides and reduced fungicide applications for control of late leaf spot. Crop Prot. 11:361-365.

13. Culbreath, A. K., Kemerait, R. C., Jr., and Brenneman, T. B. 2006. Management of early leaf spot of peanut as affected by fungicide and date of spray program initiation. Online. Plant Health Progress doi: 10.1094/PHP-20060214001-RS

14. Culbreath, A. K., Todd, J. W., Gorbet, D. W., Shokes, F. M., and Pappu, H. R. 1997. Field response of new peanut cultivar UF 91108 to tomato spotted wilt virus. Plant Dis. 81:14101415.

15. Davis, R. F., Smith, F. D., Brenneman, T. B., and McLean, H. 1996. Effect of irrigation on expression of stem rot of peanut and comparison of above and below ground disease ratings. Plant Dis. 80:1155-1159.

16. Day, J. L., Coy, A. E., Branch, W. D., May, O. L., LaHue, S. S., and Thompson, L. G., eds. 2005. 2004 Peanut, cotton, and tobacco performance tests. Ga. Agric. Exp. Stn. Rep. No. 698, Athens.

17. Day, J. L., Coy, A. E., Branch, W. D., May, O. L., LaHue, S. S., and Thompson, L. G., eds. 2006. 2005 Peanut, cotton, and tobacco performance tests. Ga. Agric. Exp. Stn. Rep. No. 703, Athens.

18. Day, J. L., Coy, A. E., Branch, W. D., May, O. L., LaHue, S. S., Thompson, L. G., and Rose, P.A., eds. 2004. 2003 Peanut, cotton, and tobacco performance tests. Ga. Agric. Exp. Stn. Rep. No. 692, Athens.

19. Fisher, R. A. 1990. Statistical Methods, Experimental Design, and Scientific Inference. Oxford University Press, Oxford.

20. Gorbet, D. W. 2003. New University of Florida peanut varieties for 2003. Marianna NFREC Res. Rep. 03-2, Mariana, FL.

21. Gorbet, D. W., Kucharek, T. A., Shokes, F. M., and Brenneman, T. B. 2004. Field evaluations of peanut germplasm for resistance to stem rot caused by Sclerotium rolfsii. Peanut Sci. 31:91-95.

22. Grichar, W. J., Besler, B. A., and Jaks, A. J. 1998. Peanut (Arachis hypogaea L.) cultivar response to leaf spot disease development under four disease management programs. Peanut Sci. 25:35-39.

23. Grichar, W. J., Besler, B. A., and Jaks, A. J. 2000. Use of azoxystrobin for disease control on Texas peanut. Peanut Sci. 27:83-87.

24. Hagan, A. K., Campbell, H. L., Bowen, K. L., and Wells, L. 2003. Comparison of Headline 2.09EC and recommended fungicides for disease control and yield response in peanut. Ala. Agric. Exp. Bull. 650, Auburn.

25. Hagan, A. K., Rivas-Davila, M. E., Bowen, K. L., and Wells, L. 2004. Comparison of fungicide programs for control of early leaf spot and southern stem rot on selected peanut cultivars. Peanut Sci. 31:22-27.

26. Hoogenboom, G., Coker, D. D., Edenfield, J. M., Evans, D. M., and Fang, C. 2003. The Georgia Automated Environmental Monitoring Network: 10 years of weather information for water resources management. Pages 896-900 in: Proc. 2003 Ga. Water Resour. Conf. K. J. Hatcher, ed. Institute of Ecology, University of Georgia, Athens.

27. Kemerait, R. C., Jr. 2004. Peanut. Page 10 in: 2003 Georgia Plant Disease Loss Estimates. J. L. Williams-Woodward, ed. Univ. Ga. Coop. Ext. Ser. Athens.

28. Kemerait, R. C., Brenneman, T. B., and Culbreath, A. K. 2004. A risk index for leaf spot and soilborne diseases of peanut in Georgia. Pages 83-90 in: 2003 Ga. Peanut Res. Ext. Rep. T. B. Brenneman and C. L. Butts, eds. Univ. Ga. Coop. Ext. Ser. U.S. Dep. Agric.

29. Kemerait, R. C., Brenneman, T. B., and Culbreath, A. K. 2005. Peanut disease control Pages 122-123 in: 2005 Georgia Pest Management Handbook, Commercial ed. P. Guillebeau, ed. Univ. Ga. Coop. Ext. Ser. Athens

30. Lamb, M. C., Masters, M. H., Rowland, D., Sorenson, R. B., Zhu, H., Blankenship, P. D., and Butts, C. L. 2004. Impact of sprinkler irri- gation amount and rotation on peanut yield. Peanut Sci. 31:108-113.

31. Melouk, H. A., and Backman, P. A. 1995 Management of soilborne fungal pathogens. Pages 75-82: in Peanut Health Management. H. A. Melouk and F. M. Shokes, eds. American Phytopathological Society, St. Paul, MN.

32. Monfort, W. S., Culbreath, A. K., Stevenson, K. L., Brenneman, T. B., Gorbet, D. W., and Phatak, S. C. 2004. Effects of reduced tillage, resistant cultivars, and reduced fungicide inputs on progress of early leaf spot of peanut (Arachis hypogaea). Plant Dis. 88:585-564.

33. Nutter, F. W., Jr., and Shokes, F. M. 1995 Management of foliar diseases caused by fungi. Pages 65-74 in: Peanut Health Management. American Phytopathological Society, St. Paul, MN.

34. Rodríguez-Kábana, R., Backman, P. A., an Williams, J. C. 1975. Determination of yield losses to Sclerotium rolfsii in peanut fields. Plant Dis. Rep. 59:855-858.

35. Shaner, G., and Finney, P. E. 1977. The effect of nitrogen fertilizer on expression of slow mildewing resistance in Knox wheat. Phytopathology 67:1051-1056.

36. Smith, D. H., and Littrell, R. H. 1980. Management of peanut foliar diseases. Plant Dis. 64:356-361

37. Smith, N. B. 2005. 2005 Georgia crop enterprise cost analysis. AGECON-94-010-S (revised), Univ. Ga. Coop. Ext. Ser. Athens.

38. USDA-AMS. 2003. Farmers' stock peanuts inspection instructions. Fruit and Vegetable Division, Fresh Products Branch. Handbook Update 133. U.S. Government Printing Office, Washington, DC.

39. USDA-FSA. 2005. 2005 Crop peanut loan rates by type. Notice LP-1996. U.S. Government Printing Office, Washington, DC.

40. USDA-FSA. 2005. Peanut loan repayment and loan-making enhancements using county release No. 501. Notice PS-454. U.S. Government Printing Office, Washington, DC.

41. William, E. J., and Drexler, J. S. 1981. A nondestructive method for determining peanut pod maturity. Peanut Sci. 8:134-141. 